\title{
Yellow Peril and cash cows: the social positioning of Asian international students in the USA
}

\author{
Christina W. Yao ${ }^{1} \cdot$ Chrystal A. George Mwangi ${ }^{2}$
}

Accepted: 5 January 2022 / Published online: 13 January 2022

(c) The Author(s), under exclusive licence to Springer Nature B.V. 2022

\begin{abstract}
Asians and Asian Americans in the USA have long been a part of a contentious racial history, yet the COVID-19 pandemic highlighted discriminatory stereotypes and beliefs. As revealed through this discourse analysis, Asian international students were simultaneously positioned as scapegoats, bearers of disease, cash cows, and political pawns, all within the context of the pandemic. Asian international students navigated their shifting social positionings within a national context that was heavily influenced by racist nativism. Findings indicated that during a health pandemic, Asian international students were positioned as both the Yellow Peril and cash cows within U.S. higher education.
\end{abstract}

Keywords International students $\cdot$ Asian $\cdot$ Racist nativism $\cdot$ Higher education $\cdot$ Social positioning · United States

COVID-19 was first identified as an infectious disease in Wuhan, China, in December 2019. In subsequent months, fear of the virus permeated the globe as countries scrambled to contain and manage the effects of the virus. When COVID-19 was first tracked in the United States (U.S.) in January 2020, Asians and Asian Americans experienced racist and discriminatory attacks fueled by bigotry and fear of the virus (Yan et al., 2020). Simultaneously, President Trump tweeted and later defended his use of the term "Chinese virus" and "kung flu" to refer to COVID-19 (Kuo, 2020). These many acts that singled out Asians and Asian Americans are reminiscent of the historical Yellow Peril concept that began in the early nineteenth century within the United States, in which Asians, specifically Chinese people, were considered forever foreigners as bearers of disease and scapegoats for economic competition (Ho, 2020; Lee, 2007). As a result, COVID-19 became a racialized global virus that contributed to distrust, blame, and retaliatory acts against Asians and Asian Americans.

Christina W. Yao

cy9@mailbox.sc.edu

Chrystal A. George Mwangi

chrystal@educ.umass.edu

1 Department of Educational Leadership and Policies, University of South Carolina, Columbia, USA

2 Department of Educational Policy, University of Massachusetts Amherst, Research \& Administration, Amherst, MA, USA 
The COVID-19 epidemic unveiled racist and xenophobic practices and policies rooted in nationalism and protectionism of the United States. Racist and discriminatory acts on college campuses against Asian students were publicized at the Binghamton University (Hupka, 2020), Angelo State University (Trammell, 2020), and Castleton University (Juan, 2020) in March 2020. After college students had to adjust their spring semester, international students in the United States were suddenly told by the U.S. Immigration and Customs Enforcement (ICE) in July 2020 that they could not take a fall course load consisting of fully online classes (U.S. Immigration and Customs Enforcement, 2020). Although later rescinded, current and incoming international students faced the uncertainty of their visa status if they attend institutions or degree programs that announced fully online fall courses.

Despite the exclusionary actions of the U.S. government, U.S. higher education institutions typically valued and viewed international students as "cash cows" (Choudaha, 2017, p. 5), serving as financial sources for economic gain (Fries-Britt et al., 2014; Stein \& de Andreotti, 2016; Yao \& Viggiano, 2019; Yao et al., 2019). Yet with the onset of a global health crisis, Asian international students experienced shifts in positioning between being perceived as economic assets and as sources of an unpredictable disease. As a result, Asian international students in the United States navigated the racial and xenophobic dynamics of COVID-19 as both cash cows and sources of the Yellow Peril within contemporary contentious times.

Although some Asian international students' experiences with racism during the pandemic have been highlighted in various news outlets, little research has been done to more closely examine how international students, especially those from Asian countries, experienced and navigated shifting social positions during the COVID-19 pandemic. Given limited research, it is important to consider multiple information sources (e.g., media, policy) to help understand the COVID-19 context for Asian international students. Analyzing the common discourses across these outlets can help elucidate the changing nature of how Asian international students are positioned in the United States, which will likely impact how these students perceive U.S. higher education and how U.S. higher education institutions engage these students into the future. The purpose of our paper is to illuminate how Asian international students have been positioned as both economic assets and bearers of an extremely contagious disease within the racialized contexts of the United States in the contentious year of 2020. We seek to answer the question: how do research, media, and policy discourses related to the COVID-19 pandemic position Asian international students?

Students from Asia are typically the largest international student population on U.S. campuses (Institute of International Education [IIE], 2019). Asian international students consisted of over half 735,000 students in the 2018/2019 academic year, comprising 65\% of the total international student population in the United States (IIE, 2019). Despite being the largest international student population, Asian international students reported feelings of isolation and marginalization (Lee, 2010; Sherry et al., 2010; Yao, 2018) prior to the start of the pandemic. These negative experiences often lead to difficulties in academic and co-curricular activities and spaces, which was especially pronounced for Asian students when compared with European nationals (Lee, 2010; Lee \& Rice, 2007; Li \& Kaye, 1998; Smith \& Khawaja, 2011; Wilton \& Constantine, 2003). Regions of origin may affect international students' transition to the United States, most notably with issues of isolation and social connections. Thus, although Asian international students were experiencing discriminatory behaviors prior to the pandemic, current anti-Asian sentiment as a result of the COVID-19 pandemic necessitates a closer examination of how these students are positioned within current discourse. 
Despite the diversity of cultures and national origin within the Asian population, we chose to focus broadly on Asian international students rather than solely on Chinese international students who we recognize may be more affected by xenophobic and racist rhetoric such as "China virus." This is not meant to homogenize Asian international students but to acknowledge, after reviewing current literature and news reports, that people from multiple Asian ethnicities have experienced discrimination during the pandemic due to mistakenly being racialized as Chinese or because of broader anti-Asian sentiments. Thus, we focus broadly on Asian people, although we do specify ethnicities when possible. In addition, we chose to bound our study within the United States context. We recognize that anti-Asian sentiment permeated many contexts around the world, yet we believe that the United States can provide a unique case that includes relevant sociohistorical foundations that have led to current policies and discourse (i.e., U.S. Immigration and Customs Enforcement's Student and Exchange Visitor Program (SEVP) policy) that are best examined within one countryspecific context.

In the next sections, we first provide an overview of our conceptual framing, which is guided by racist nativism and social positioning, to set the stage for the discussion and analysis. We include the historical foundations of Yellow Peril and contemporary literature related to international students as cash cows in our analysis. We then map contemporary discourse about Asian international students using the conceptual framing and previous literature and conclude with future directions for research, theory, and practice.

\section{Conceptual framing}

We combine racist nativism and group positioning theory as our conceptual framing. Asian international students' experiences with racism are intersected by a U.S. sociopolitical climate steeped in xenophobia, protectionism, anti-globalist rhetoric, and nationalism. This climate is mirrored in U.S. universities in which there are documented upticks in hate speech, the development or reification of existing nativist policies, and anti-immigrant sentiment (Franklin \& Medina, 2018; Rose-Redwood \& Rose-Redwood, 2017; Rushin \& Edwards, 2018). Racist nativism provides a way to understand the higher education context for Asian international students as it is defined as.

the assigning of values to real or imagined differences, in order to justify the superiority of the native, who is to be perceived white, over that of the non-native, who is perceived to be People and Immigrants of Color, and thereby defend the right of whites, or the natives, to dominance (Perez Huber et al., 2008, p. 43).

People and immigrants of Color, therefore, are often labeled as perpetual foreigners and perceived as "non-native... and not belonging to the monolithic "American' identity" (Perez Huber, 2011, p. 382). As a result, Asian individuals, no matter their immigration status in the United States, become and remain othered and marked as different from white dominant U.S. citizens.

Racist nativism has been rooted in Latino Critical Race Theory (LatCrit), an offshoot of Critical Race Theory (CRT). Although the population emphasized in this analysis are Asian international students, we argue that racist nativism can be broadened to include racialized international students who, similar to Latinx populations in Perez Huber's (2011) study and other transnational groups, are "racialized as nonnatives regardless of actual immigration status" (p. 382). Because racist nativism is based on others' perceptions, the 
positioning of Asian international students becomes "a function of white dominance" (p. 382) that has permeated the globe as evidenced by COVID-19. Race and racial systems flow and shift based on transnational processes because we exist in "a world racial system" (Winant, 2004, p. xvi). Asian international students are greatly affected by racist nativism because "race moves under the intensification of transnational flows and connections" (Mishra Tarc, 2013, p. 365). Within the COVID-19 pandemic, xenophobia and othering have contributed to the already uncertain time of a global health crisis.

The racist nativism affecting international students reflect two of Asian Critical Race Theory's (AsianCrit) tenets, specifically that of Asianization and transnational contexts (Iftikar \& Museus, 2018; Museus \& Iftikar, 2013). Asianization focuses on how U.S. society "lumps all Asian Americans into a monolithic group" (Museus \& Iftikar, 2013, p. 23) and is often manifested in "polarized extremes" (p. 24) that is dependent on the needs and perceptions of the white majority. Transnational contexts, as described by Iftikar and Museus (2018), "emphasize the importance of situating Asian Americans and the operation of White supremacy within a network of global relationships" (p. 940), which is particularly salient considering the global pandemic. Although Asian international students may not be considered to be Asian American, international students to the United States are often "othered and racialized using U.S.-constructs of race" (Yao et al., 2019, p. 39), thus making some tenets of CRT, LatCrit, and AsianCrit appropriate lenses for examining this student population.

We consider the racist-nativist attitudes toward Asian international students through the lens of Blumer's (1958) group positioning theory. Blumer suggested that racial attitudes stem from "historically and collectively developed judgments about the positions in the social order that in-group members occupy relative to members of an out-group" (p. 5). Within this theory, groups are positioned according to beliefs of in-group superiority and preference, with in-group members viewing out-groups as "alien" and "different." In the United States, a racial hierarchy exists that reinforces the dominant group's position and privileges. In doing so, populations considered "of Color" are positioned as the "other" beneath those who are perceived to be white and American (Lee et al., 2004). In the case of Asian international students, this population is positioned as an out-group by dominant U.S. society on various levels: (1) as foreign-born individuals and (2) as non-white individuals. Group positioning theory highlights assumptions about who can lay claim to resources, rights, privileges, and status reflect in-group sense of group position and belief that out-group members desire a larger share of power. Because many in the United States believe China is attempting to overtake the U.S.'s dominance as a superpower, Asian international students may also be perceived, as a group, as a contributor to this perceived goal. In combining racist nativism with group positioning theory as our conceptual framework, we are able to understand the structural and systemic challenges that Asian international students experience as a result of their race, nativity, and nationality (i.e., racist nativism) alongside how these students' positioning is defined and prioritized via research, media, and policy (i.e., group positioning theory).

\section{Methodology}

We used critical discourse analysis (CDA), which allowed us to examine how textual language reproduce issues of dominance, inequality, and power as well as how underlying agendas, motivations, and ideologies are reflected in texts (Janks, 1997; van Dijk, 2008; 
Wodak, 1995). It emphasizes interpretations of social constructions of reality and their (re) production (Hardy et al., 2004). We utilized Fairclough's $(1989,1995)$ three dimensions of critical discourse analysis. Fairclough (1993) emphasized the investigation of how "practices, events, and texts arise out of and are ideologically shaped by relations of power and struggles over power; and to explore how the opacity of these relationships between discourse and society is itself a factor securing power and hegemony" (p. 135). Fairclough's centering on discourse as a social practice and mode of action connected to power aligns with our assumptions that the texts and discourses we analyzed not only describe, but serve to inform and reinforce the ways in which international students' racial positioning has evolved during the COVID-19 context.

Additionally, Fairclough's approach to CDA supports drawing upon different, but interrelated genre-texts that revolve around the same content. Fairclough (2001) describes the intertextual and interdiscursive nature of discourse found across multiple texts, sites, and genres that can serve to maintain the status quo and inequality within a social issue. Similarly, we critically examined the discourse(s) present in U.S. research, media, and policy regarding Asian international students within the COVID-19 pandemic context. We also found a number of examples of intertextuality within the documents we analyzed with both news articles citing available research, but also research articles citing media pieces. This degree of intertextuality within a smaller body of work may be due to the limited amount of empirical research available at the time of our analysis. It is rare for academic research to be conducted and disseminated at a fast pace, but the COVID-19 context presented rare times and a commitment by some to find a way to contribute to knowledge generation and discourse, which we chose to have represented within our analysis. This combination of academic and non-academic documents within CDA is an approach that has been successfully used in previous research contributions to international higher education (e.g., Marginson, 2008; Yao, 2021).

\section{Search procedures and sample}

The data sources for this study included empirical studies, news articles, white papers, and policy briefs. We first conducted a database search for empirical articles using Academic Search, ERIC (EBSCO), Education Source and ERIC, PsychInfo, and Social Sciences Citation Index. We searched using the terms COVID AND United States AND [international student, higher education, Asian, Chinese]. Using these inclusion criteria for our systematic inquiry, we conducted a comprehensive search that reflected a purposive sampling technique (Saini \& Shlonsky, 2012). This led to 446 journal articles being retrieved through our search process. Next, we reviewed documents to ensure relevance to our topic and include only studies conducted in the United States. As a result, we removed 412 documents, and the remaining 34 articles reflect relevance to our topic.

We conducted our search for news articles, white papers, and policy briefs by first reviewing the empirical articles for any mention of relevant references. We also conducted a search with Google as the search engine, using keywords such as "COVID-19," "Asian students," and "international students." As a result, we found multiple news articles from the Chronicle of Higher Education and Inside Higher Ed. We also included the press releases from U.S. Immigration and Customs Enforcement that announced the SEVP COVID-19 guidance affecting international students. In addition, several policy publications and press releases from national associations such as NAFSA and the American 
Council on Education were added to our sample, including an amicus brief that was spearheaded by the American Council on Education.

\section{Data analysis}

Fairclough $(1989,1995)$ developed three interdependent forms of analysis. The first phase focused on discourse-as-text or descriptions of text. To pursue this description, we read and summarized each document. The summaries included the type of document (e.g., empirical study, public policy document, media article), stated purpose of the document, actions/ implications/recommendations that the document called upon, and our perception of the intended audience.

During this phase, we also created checklists that we used to develop an in-depth description of the content of the documents in a uniform manner. The checklists were informed by our conceptual framework and research questions, allowing us to consider what content was being produced and reproduced through the documents (Fairclough, 1989). The checklists included questions such as "How does this document describe Asian international students?" and "Whose needs and concerns are centered in the document?" For each article, we responded to each question, which included pulling direct quotations from the article to support our claims (see Appendix I for an example from one of our data analysis sheets). For example, in response to the question "Does the document use the word 'racism,' 'prejudice,' 'bigotry' 'xenophobia,' or any words similar to these? If so, how/in what context?," we stated that in one article "Prejudice is used as a foundational construct in this article as is stigmatization. Xenophobia and racism are connected to stigmatization to demonstrate how Americans use stereotypes to vilify Asians international students regarding COVID-19." We provided the following sentences from the article as one form of evidence to support our description:

Due to the asymptomatic nature of the virus, individuals are turning to other nonhealth related traits to purportedly identify potential carriers. One of the more disturbing trends is the increase in prejudice directed toward those of Asian descent springing from systemic racism rooted in century-old stereotypes. (Roberto et al., 2020, p. 369)

Additionally, we checked for consistency between our independent analyses by selecting and reviewing each other's responses to ensure that we remained consistent with our interpretations (Maxwell, 2005).

We then continued with Fairclough's $(1989,1995)$ second component for CDA which included interpreting how the texts were produced and may be received by the reader (discourse-as-discursive practice). This process focuses on discourse as social practice and emphasizes how the documents reflect broader social relations of power and knowledge. We began collapsing our responses across the documents to focus on how they reflected the social positioning of Asian international students within the COVID-19 context. During this process, we reduced the data into four common and consistent discourses that we interpreted across the documents to reflect Asian international students as scapegoats, bearers of disease, cash cows, and political pawns. Each of the four discourses is used to frame our subsequent findings and provides readers with evidence across the documents to support our interpretations. While they are each described individually for clarity, the discourses are not mutually exclusive; for example, the aforementioned quote in the document by Roberto et al. (2020) reflects Asian international students as both scapegoats to blame 
for COVID-19 and bearers of disease ("individuals are turning to other non-health related traits to purportedly identify potential carriers").

The third component is social analysis or explanation (Fairclough, 1989). During this phase, we emphasized the sociohistorical, geopolitical, economic, and cultural conditions that might have led to the production of the documents. For example, we re-engaged with literature on the history of Yellow Peril and developed analytic memos on its connection to the construction of contemporary discourse around Asian international students as bearers of disease found in the documents we analyzed. As another example, we engaged in written reflection and dialogue about the historical and more current political relationship between the United States and China as well as how that relationship was presented in the documents we analyzed and may have influenced their production by U.S.-based. In developing our findings, we chose to combine them with our discussion section in order to situate our interpretations of the discourses within broader social relations of power and knowledge and more directly explain how these social relations are presented and reified in texts (Fairclough, 1989, 1995).

\section{Trustworthiness and researcher positionalities}

We recognize that the meaning making of discourse is rooted in our own perspectives and positionalities to the topic. The first author identifies as a U.S.-born, Asian American woman, born and raised in the United States by immigrant parents. Her parents were products of British colonial Hong Kong and as a result navigated multiple status and nationalities throughout their lives as Chinese colonial subjects and naturalized U.S. citizens. The first author currently serves as a faculty member in the Southeastern United States and primarily researches the experiences of international students of Color in the United States. The second author is a faculty member in the U.S. mid-Atlantic region who identifies as an African American woman with West Indian/Caribbean heritage. Her father and spouse, who both racially identify as Black, emigrated to the United States to pursue higher education as temporary sojourners but remained permanently after graduating. Their experiences with racism and xenophobia in U.S. higher education led to her interest in empirically understanding how race, ethnicity, and nativity are intersected in the othering of international students.

We were both born in the United States and educated within the U.S. educational system. Although we do not personally claim immigrant or international status, we are both products of our upbringings that included global perspectives and first-hand views at how racism, social positioning, and racist nativism can affect both individuals and groups. Thus, we approached this study with care and attentiveness to how we interpreted the reviewed documents.

There were many benefits to collaborative analysis as we engaged in multiple ways of seeing the data. We continuously engaged in discussion and debate about our analyses, which allowed us to illuminate and fill in gaps that would not be easily seen by only one researcher (Denzin, 1978). In our discussions, we would provide feedback on each other's interpretations as well as collectively make meaning of our findings and analyses. When constructing our many drafts, we would continuously refine and revise our findings, especially related to our themes as we re-reviewed documents. Throughout this process, we were able to engage in a collaborative analysis as we made meaning of the discourses in multiple texts. 


\section{Critical analysis and discussion}

In our review of articles and news sources, we found that Asian international students were positioned both negatively and positively throughout the COVID-19 pandemic. Negative attributions of Asian international students included their positioning as scapegoats for general society's anger at having to live within a global health crisis. In addition, Asians and Asian Americans experienced discrimination and racism as a result of being labeled as disease bearers. Yet discrimination against international students is nothing new because international students are often (re)racialized within the U.S. context, especially for students who come from non-white and non-English-speaking countries (Yao et al., 2019). As a result, many international students may be considered racial and/or ethnic minorities in the United States, which may expose them to racism and discrimination (Fries-Britt et al., 2014; Hanassab, 2006; Yao, 2018), all of which are heightened during COVID-19. Thus, beyond the typical transition issues that Asian international students may experience, the current challenges with COVID-19 illuminate additional layers of racism and nativism within a global health crisis.

In addition, the Student and Exchange Visitor Program (SEVP) of the U.S. Department of Homeland Security issued policy modifications for temporary exemptions that allowed nonimmigrant students to take online classes due to the pandemic (U.S. Immigration and Customs Enforcement, 2020). The modifications stated that all nonimmigrant (international) college students who wish to remain in or come to the United States for fall 2020 may not take a course load consisting of fully online classes. Simply stated, international students would not receive or keep their visas if they attend institutions or degree programs that have announced fully online fall courses. In the case of fully online programs, students' options are to leave the U.S. or face deportation. Many higher education institutions and associations spoke out against the policy, yet often in commodifying terms that benefit the United States. Within the context of a contentious year, we found that Asian international students were simultaneously positioned as scapegoats, bearers of disease, cash cows, and political pawns in our analysis of current literature and news sources, all within the context of the COVID-19 pandemic.

\section{Scapegoats and racial targets of the Yellow Peril}

The fear of Asian individuals is welded into the fabric of the United States, as evidenced by history and contemporary issues. Asian history in the United States began with the arrival of Chinese and Japanese immigrants, primarily for labor reasons and settling on the West coast. Their arrival caused significant racism and hostility from the white Americans at that time due to perceived employment competition, and the U.S. government also explicitly discriminated against Asian people in their policies and practices in early history (Lee, 2004). Ultimately, Asian people in the U.S. represented the Yellow Peril, which refers to fear and mistrust of Asian individuals that categorizes Asians as forever foreigners (Ho, 2020; Lee, 2007). As forever foreigners, Asian people are often considered the other, as theorized by Said (1978) in his explanation of Orientalism. Since the early nineteenth century, Asians have been "described as inassimilable aliens who brought economic competition, disease, and immorality" (Lee, 2007, p. 537), with the disease aspect evident during the SARS outbreak in 2003 (Lee, 2020a, 2020b). As indicated by current events in COVID-19 (e.g., Kuo, 2020; Yan et al., 2020), Asians in the United States are now currently marked with being bearers of disease 
and reflect the transnational contexts tenet of AsianCrit (Iftikar \& Museus, 2018; Museus \& Iftikar, 2013). As a result, Asian international students in the United States must navigate their shifting positionalities within a racialized global crisis.

Negative attitudes toward Asian individuals have historical foundations that have become more visible in light of the current pandemic. As stated by Litam (2020), "racial discrimination, microaggressions, and Sinophobic behaviors are not limited to the current pandemic and instead represent longstanding forms of oppression embedded in American history and culture" (p. 151). These instances of racist nativism and Asianization were visible in previous crises affect Asians and Asian Americans, most notably the 9/11 attacks which sparked antiMuslim sentiment. In the earlier stages of the pandemic, fears of COVID-19 infections were based on the high possibilities of asymptomatic carriers (del Rio \& Malani, 2020). Thus, as stated by Roberto et al (2020), many individuals turned "to other non-health related traits to purportedly identify potential carriers" (p. 369). Because the virus allegedly started in Wuhan, China, people who are racialized as Asian were positioned and othered as carriers of this contagious virus as a result of Asianization. The stereotypes increased the "outgroup stigmatization and negative behavioral responses" (Roberto et al., 2020, p. 369) of Asians individuals.

Another way in which Asian international students were presented in the articles was as scapegoats who were blamed for the COVID-19 pandemic. As Kim and Shah (2020) explained, "The current president of the United States and his administration referring to COVID-19 as the 'Chinese virus' or the 'Kung-flu' has only legitimized some people's willingness to use derogatory terminologies" (p. 605). As the Chinese became the scapegoats for COVID-19 within the United States, Chinese international students (as well as other Asians and Asian Americans) experienced heightened racism and anti-Asian violence. A number of articles we reviewed quoted upticks in reports of discrimination to the \#StopAAPIHate campaign created by the Asian Pacific Policy and Planning Council (e.g., Kim \& Shah, 2020; Le et al., 2020; Man, 2020).

The notion of "foreigner threat" underlies the racist-nativist treatment of Asian international students as scapegoats in which "the perception of a foreign threat of invasion and harm, [makes it] normative to center White culture and well-being in system-level narratives," (Kim \& Shah, 2020, p. 607). In this way, Asian international students are positioned not as valued human beings but as a threat to the safety and well-being of (white) Americans. Their mistreatment began and became validated at the federal government level through both immigration policies and political speech acts made by the former president, with a trickle-down effect into how Americans on college campuses and in local campus towns treated them via wariness, discrimination, and violence.

A number of articles we reviewed focused on the negative implications that the COVID19 context was having on international students relating to mental health such as "emotional breakdown" (Anandavalli et al., 2020) and trauma (Litam, 2020) as well as professional/ academic outcomes with "the potential to disrupt their lives and drastically alter their futures" (Specia \& Abi-Habib, 2020). Authors discussed the need for U.S. higher education institutions to support and accommodate international students given how they were being positioned as scapegoats and victims of anti-Asian violence and nativism.

\section{International students as cash cows and political pawns}

Although many higher education institutions and associations vocalized their support of international students in the United States, the arguments can be viewed through an interest convergence lens. Centered in the work of Critical Race Theory to explain 
Black-White relations in the United States, interest convergence reflects the idea that the dominant group will only support the needs of the marginalized if those interests converge in some way with that of the dominant group (Bell, 1980). Within the context of our study, our analysis demonstrates the fight to keep international students in the United States served the purposes and needs of those in power, namely U.S. higher education institutions and associations (Yao, 2021; Yao \& Viggiano, 2019). As shared by Castiello-Gutierrez and Li (2020), "those who were fighting with and for us sometimes used language that unconsciously embraced a nationalistic perspective; they defended our place and belonging mainly based on the economic contributions and valuable talent that we bring to this country" (p. ii). U.S. colleges and universities have a vested interest in the enrollment of international students to bring in tuition dollars and research labor (commodification) and engage in soft power dynamics (political pawns). The positioning of international students, especially those from Asia, as political pawns and commodities further perpetuates them as dehumanized out-groups who protect the dominant group's social positions.

International students have often been viewed as commodities in U.S. higher education, which contributes to the United States' "the overall pursuit of academic imperialism through economic gain, institutional visibility, and international prestige" (Yao, 2021, p. 151-152). This commodification aligns with the environment of academic capitalism that has emerged as part of the contemporary neo-liberal logic. Academic capitalism drives universities to couple the pursuit of knowledge creation with production, profit maximization, and market-driven behaviors (Slaughter \& Rhoades, 2004). The pursuit of economic gains contributes to the commodification of international students by U.S. higher education in three main ways: financial contributors to the economy, inexpensive labor for research and teaching, and diversity resources for U.S. students' learning and development (George Mwangi \& Yao, 2020). As "cash cows," international students essentially serve as "a product...that provided steady, reliable cash flows to fund its growth and the growth of a company's other business units" (Choudaha, 2017, p. 5). Within the dehumanizing rhetoric of cash cows, international students serve as resources that benefit higher education institutions in the United States through multiple means, and the SEVP modification that was released during the pandemic highlighted the commodification of international students in very direct ways. The commodification affects all international students, yet this is especially salient for Asian international students who are the largest international population on college campuses in the United States (IIE, 2019). Thus, Asian international students are typically the most visible financial sources and resources that serve as cash cows for college campus.

The positioning of international students serving as financial resources tends to overshadow all other benefits and outcomes. Both the Organisation for Economic Cooperation and Development (OECD; 2016; 2020) and the Institute of International Education (IIE; 2020 ) tout the financial benefits of the U.S. hosting international students, with IIE reporting that $\$ 44$ billion were contributed by international students in 2019 . Thus, Asian international students were responsible for approximately $\$ 22$ billion to the U.S. economy that year. Because of the financial impact, many higher education institutions expressed concerns in spring 2020 about how the continuation of the COVID-19 pandemic would cause for millions in revenue loss due to low international student enrollment (Fischer, 2020b; Redden, 2020). NAFSA (2020b) conducted a survey in April 2020 on the economic impact of COVID-19 and estimated that "U.S. higher education will lose at least \$3 billion due to anticipated international student enrollment declines for fall 2020" (p. 2). Overall, the COVID-19 pandemic raised concerns across college campuses about international student 
mobility, much of it rooted in the financial implications of lower international student enrollment.

Specia and Abi-Habib (2020) described advocacy already happening on U.S. college campuses as "hundreds of thousands of students and their supporters have signed petitions demanding that the government rethink the decision and urging their universities to protect students from abroad." Yet, even as the scholarship and other documents reviewed discussed the need to support these students, this was often presented as a means of serving the United States such as this response from the American Council on Education (2020a, 2020b) which states, "Some one million international students attend U.S. colleges and universities annually, contributing greatly to this country's intellectual and cultural vibrancy. They also yield an estimated economic impact of $\$ 41$ billion and support more than 450,000 U.S. jobs." This response emphasizes the economic benefit of international students to the United States, while an amicus brief we reviewed focuses on how international students improve the reputation of U.S. higher education:

America's colleges and universities are among the finest in the world. They help preserve our democratic values, ensure the country's economic strength, and contribute to our nation's influence and global standing. A central reason for the excellence of our postsecondary institutions is their ability to attract and enroll talented, motivated, and curious students, whether born in this country or abroad. (American Council on Education, 2022a, p. 4)

Rationales for supporting Asian international students that are framed economically and reputationally portray a type of nationalistic and protectionist argument that commodifies international students and reflects that it is "normative to center White culture and well-being in system-level narratives" (Kim \& Shah, 2020, p. 607). This dehumanizing approach reinforces the othering of Asian international students that like "foreigner threat" and "model minority" stereotypes, further positions these students as less valuable human beings than (white) American citizens.

Yet even for universities desiring to retain international students, immigration policies developed during COVID-19 created devastating barriers. For example, while U.S. students were allowed to take online/remote classes in order to remain at their universities, a few weeks before the Fall 2020 semester began, ICE ordered that international students who were taking all of their courses online would be deported (ICE, 2020). As Anandavalli and colleagues (2020) expressed, "International students became tasked with an impossible decision to either prioritize their health or their education" (p. 367). Thus, in addition to being positioned as economic commodities, international students were simultaneously being used as "political pawns" (Lee, 2020a, 2020b). International students were being used as a wedge in the fight between higher education institutions remaining online for safety and the U.S. federal government attempting to force campuses to open in the fall (Lee, 2020a, 2020b). Blanco (2020) conceptualized this as "hostage taking," with international students positioned as hostages as part of the United States' "sophisticated mechanisms for the recruitment and management of hostages that mask its violence" (n.p.).

The articles we reviewed highlighted that Asian international students are experiencing exclusion at the policy level that impacts their ability to access and remain in U.S. higher education institutions. Park and Rhim (2020) describe that due to COVID-related travel restrictions, "many medical schools in the United States have canceled clinical rotations and stopped receiving visiting students" (p. 93). For other international students already in the United States, they were "stuck in the United States, stranded by travel bans" (Fischer, 2020a, p. i). 
A number of authors we reviewed discussed how this policy decision by the Trump administration used international students as political pawns to force universities to re-open or lose the students and their tuition dollars (Anandavalli et al., 2020; Park \& Rhim, 2020; Specia \& Abi-Habib, 2020). Anandavalli et al. (2020) expressed, "The presence of a discriminatory order that forced international students to choose between their safety and educational training is reflective of larger anti-immigration sentiments that push many students toward an emotional breakdown," (p. 367). Although Harvard and the Massachusetts Institute of Technology (MIT) sued the Trump administration and effectively blocked the directive, the commodifying message sent by the federal government that international students were pawns that could be bargained for or disposed of was clearly sent.

Chinese international students have been particularly made vulnerable throughout the COVID-19 context given tense geopolitical relations between the United States and China. Fischer (2020a) discussed how their enrollments had already been on the decline, "due to geopolitical tensions, tougher visa policies, and increased global competition" and expressed that "the coronavirus could be one more hit, perhaps a knockout blow" (n.p.). For example, Trump and his administration received pressure to demonstrate dominance over China during his second presidential run (Superpowered Insults, 2020). In that article, authors described that "Mike Pompeo, the secretary of state and a proponent of the term 'Wuhan virus', tweeted that 'China has a history of infecting the world', implicitly blaming the COVID-19 pandemic on 'failures in a Chinese lab' in Wuhan" (p. 16). Other Trump political supporters such as Republican Josh Hawley sponsored the "Justice for Victims of Coronavirus Act" that would "allow citizens and states to sue China for damages related to COVID-19" (Superpowered Insults, 2020, p. 17). Geopolitical strain between the two nations increased U.S. policy actions against China, but also reinforced messaging that Chinese individuals were a threat. As Roberto et al. (2020) explained, "Government policy can reflect socially constructed norms which sends signals to impacted groups about their civic worth and the nation's democratic values which successively reinforces bias, otherness, and gender, racial and class stereotypes" (p. 356).

\section{Implications and future directions: practice, theory, and research}

International students, especially those who may be considered of Color (Yao et al., 2019), are typically an afterthought on campuses in relation to diversity, equity, and inclusion when considering campus climate (George Mwangi \& Yao, 2020). There is no question that this pandemic has far-reaching negative effects for many constituents around the world, and specifically related to higher education, this pandemic amplifies the racism, xenophobia, and dehumanization that many international students experienced prior to the pandemic. Although this current pandemic may be considered a once-in-a-lifetime event, we argue that the racist nativism and social positioning of Asian international students have been around much longer than COVID-19. Rather, the current health pandemic highlighted the problematic dehumanization of Asian international students; thus, it is imperative that higher education institutions in the United States address the positioning of these students and consider ways to better support this population. In this section, we offer several suggestions for practice as well as future directions for theory and research. 


\section{Implications for practice}

We offer several recommendations for practice as higher education moves through and potentially out of this current health pandemic. Although we focus on the needs of Asian international students based on this particular analysis, we must acknowledge that specific populations may be targeted during any future global crises. Thus, our recommendations are broadly applicable for most international student populations, particularly those who may be perceived to be of Color.

First, the mental health and well-being of Asian international students must be the primary concerns for higher education institutions. As indicated by current literature and news reports, Asian international students are forced to navigate their positioning in the United States as both bearers of disease and cash cows for higher education which may cause anxiety, stress, and fear. Asian international students were conveniently positioned as scapegoats and political pawns without much concern about how the discourse may affect their mental health and well-being. Thus, we urge higher education institutions to consider ways to more effectively and culturally sustain support to international students, especially during global crises.

In addition, the discourse revealed the many discriminatory acts and words that Asians and Asian Americans faced during the pandemic. Several reports of racist and discriminatory acts at colleges and universities were publicized in the early days of the pandemic (Hupka, 2020; Juan, 2020; Trammell, 2020), yet it is likely that there were more issues that went unreported. We suggest that higher education institutions provide clear and direct pathways for reporting bias incidents both on and off campus. We also encourage that institutions address students' fears of retaliation that may put their visa statuses in jeopardy. Simply stated, higher education institutions must clearly communicate to international students that they will be protected from possible negative outcomes if they choose to report bias incidents.

Although the ICE direction in summer 2020 received significant attention, immigration policies and laws have fluctuated for many years. Changes to immigration policies cause stress and anxiety for international students, especially for those from countries that are on lists of restricted countries due to political tensions. Thus, we suggest that institutions increase their collaborative efforts across offices to provide a continuous network of support for international students, including student affairs, academic affairs, graduate, and professional schools. As indicated by our analysis, many international students were constrained by U.S. policies that impacted their abilities to travel and potentially enroll in U.S. institutions. Higher education professionals, especially those who work in international students and scholars offices, must navigate their dual positions as being both arms of the federal government and student advocates. Despite the complexity of roles, all higher education professionals have a responsibility to address issues related to fears of racism and immigration policy changes both reactively and proactively.

\section{Implications for theory}

International students in the United States are not demographically categorized according to their race in most U.S. higher education institutions, which makes further invisible their experiences with racialization and racism on their campuses and the ways in which their experiences are nuanced from U.S. students. Although racist nativism is a construct that 
has been used to discuss Latinx populations in higher education (see Perez Huber et al., 2008), our analysis demonstrates the utility of this construct to understanding the experiences of Asian international students who experience marginalization at the intersections of their race and nativity. For example, while the model minority myth can at first glance be perceived as a positive depiction of Asian international students, racist nativism makes clear that this stereotype serves to homogenize Asians in the United States and support racial wedges between Black, Indigenous, and other groups in order to perpetuate white dominance (Poon et al., 2017).

Group positioning theory also supports understanding in how racial positioning of Asian international students in the United States remains situated within a white supremacist system. Although the COVID-19 context is a contemporary issue, our analysis demonstrates the longevity of Asians' positioning within U.S. society as diseased and a foreign threat. Further expansion of these constructs (i.e., racist nativism and group positioning) to interrogate and connect other key sociohistorical (e.g., Yellow Peril) and contemporary (e.g., commodification) issues impacting Asian international students will support making visible their experiences with race and nativity in the United States.

\section{Limitations and recommendations for future research}

We made the decision to bound this study within the United States, which we recognize contributes to methodological nationalism (Chernilo, 2007). In order to expand beyond this limitation, we suggest that additional studies need to be conducted that go beyond the U.S. national container (Shahjahan \& Kezar, 2013). Anti-Asian discrimination during the COVID-19 pandemic was not unique to the United States, and a larger global study would provide insights on how racism and discrimination flow throughout the world, particularly during a global health crisis. The findings and implications from this current study are valuable in understanding the complexities of Asian international students' positioning in the United States during the pandemic; however, we suggest caution in assuming that our findings are immediately relevant in all other national contexts. Rather, we suggest that our findings can be valuable as long as individual national contexts, including historical foundations and current issues, are taken into consideration.

Our study was conducted in the midst of the ongoing pandemic, and as a result, our findings and analysis do not span the entire COVID-19 outbreak which may serve as a limitation. We recognize that Asian international students' position may change over time, yet there is value in viewing and understanding their positioning during what was seemingly the height of contemporary anti-Asian sentiment. Our study served as one bounded time period within the ongoing pandemic; however, the value of this particular study demonstrated that historical prejudices were brought to the forefront during a contemporary global health issue.

While our study provides value in understanding media and policy discourses regarding Asian international students during the COVID-19 context, it is important for future research to move this work forward through empirical qualitative and/or quantitative inquiry. One recommendation is for scholars to pursue research that examines how Asian international students have made meaning of the media and policy discourses about them during COVID-19. This might include current students who are navigating higher education in the United States or prospective students who are deciding whether or not to pursue U.S. higher education. Understanding how these students perceive and internalize 
messages, like the ones shared in our study, could help to inform more effective ways of recruiting and supporting Asian international students into the future.

Many of the articles we reviewed did not focus on Chinese international students but instead focused more broadly on Asian international students or all international students. This limited our ability to emphasize the experiences of Chinese international students specifically. We recommend researchers disaggregate international student data and Asian student data because not doing so perpetuates an essentialist perspective that is situated within racist nativist framings of these students as "all the same." For example, given the geopolitical tensions between the United States and China and the discourses about COVID-19's connections to China, it is important to conduct research that emphasizes the unique and nuanced experiences of Chinese international students during the pandemic.

Lastly, we recommend scholars conduct research that investigates how higher education institutions have navigated the policy changes regarding international students in the United States, for example, research that includes the perspectives and experiences of senior campus leaders, international student services staff, and admissions office staff who had to make policy implementation decisions. Many campus administrators put out public statements to their campus broadly or to international students specifically about what their universities would do to work with this student population during COVID-19. Future researchers could develop an analysis of these statements as a standalone study or in combination with other forms of data to elucidate institutional level discourses related to Asian international students and the COVID-19 context.

\section{Conclusion}

Asians and Asian Americans in the United States have long been a part of a contentious racial history, yet the current health pandemic indicates that contemporary events may trigger seemingly bygone stereotypes and beliefs. As revealed through this discourse analysis, Asian international students were simultaneously positioned as scapegoats, bearers of disease, cash cows, and political pawns, all within the context of the COVID-19 pandemic. Asian international students navigated their shifting social positionings within a national context that was heavily influenced by racist nativism. Findings from this analysis illuminate how a health pandemic dehumanized Asian international students as both the Yellow Peril and cash cows; thus, it is imperative that higher education institutions in the United States address their positioning and ways to support this population of students.

Supplementary Information The online version contains supplementary material available at https://doi. org/10.1007/s10734-022-00814-y.

\section{Declarations}

Conflict of interest The authors declare no competing interests.

\section{References}

American Council on Education. (2020a). Brief of the American Council on Education and 70 other higher education organizations as amici curiae in support of plaintiffs' motion for preliminary injunctive relief. https://www.aacrao.org/docs/default-source/statements-and-letters/amicus-brief-mass-districtcourt-sevp-071320.pdf?sfvrsn=9953a6a1_3 
American Council on Education. (2020b, July 6). Statement by ACE president Ted Mitchell on ICE guidance on international students. https://www.acenet.edu/News-Room/Pages/Statement-by-ACEPresident-Ted-Mitchell-on-ICE-Guidance-on-International-Students.aspx

Bell, D. A. (1980). Brown v. Board of Education and the interest-convergence dilemma. Harvard Law Review, 93(3), 518-533. https://doi.org/10.2307/1340546

Blanco, G. L. (2020). International students and hostage taking. Critical Internationalization Studies Network. https://criticalinternationalization.net/2020/07/09/international-students-andho stage-taking/

Blumer, H. (1958). Race prejudice as a sense of group position. Pacific Sociological Review, 1, 3-7. https://doi.org/10.2307/1388607

Chernilo, D. (2007). A social theory of the nation state: The political forms of modernity beyond methodological nationalism. Routledge.

Choudaha, R. (2017). Are International Students "Cash Cows"? International Higher Education, 90, 5-6. https://doi.org/10.6017/ihe.2017.90.9993

del Rio, C., \& Malani, P. N. (2020). COVID-19-New insights on a rapidly changing epidemic. JAMA, 323(14), 1339-1340. https://doi.org/10.1001/jama.2020.3072

Denzin, N. K. (1978). The research act: A theoretical introduction to sociological methods (2nd ed). McGraw-Hill.

Fairclough, N. (1989). Language and power. Longman.

Fairclough, N. (1993). Critical discourse analysis and the marketization of public discourse: The universities. Discourse \& Society, 4, 133-168. https://doi.org/10.1177/0957926593004002002

Fairclough, N. (1995). Critical discourse analysis. Longman.

Fairclough, N. (2001). Critical discourse analysis as a method in social scientific research. In R. Wodak \& M. Meyer (Eds.), Methods of critical discourse analysis (pp. 121-138). Sage Publications.

Fischer, K. (2020a). Enrollment headaches from Coronavirus are many. They won't be relieved soon. The Chronicle of Higher Education. https://www.chronicle.com/article/enrollment-headachesfrom-coronavirus-are-many-they-wont-be-relieved-soon/

Fischer, K. (2020b). With coronavirus keeping them in U.S., international students face uncertainty. So do their colleges. The Chronicle of Higher Education. https://www.chronicle.com/article/WithCoronavirus-Keeping-Them/248201?cid=cp275

Franklin, J. D., \& Medina, R. (2018). Trump and an anti-immigrant climate: Implications for Latinx undergraduates. Journal of Critical Scholarship on Higher Education and Student Affairs, 3(3), 74-85.

Fries-Britt, S., George Mwangi, C. A., \& Peralta, A. M. (2014). Learning race in a US Context: An emergent framework on the perceptions of race among foreign-born students of color. Journal of Diversity in Higher Education, 7(1), 1.

George Mwangi, C.M., \& Yao, C.W. (2020). U.S. higher education internationalization through an equity driven lens: An analysis of concepts, history, and research. In M. B. Paulsen \& L. W. Perna (Eds) Higher Education: Handbook of Theory and Research (Vol. 35). Springer.

Ho, J. (2020). Anti-Asian racism and COVID-19. Colorado Arts and Sciences Magazine. https://www. colorado.edu/asmagazine/2020/04/08/anti-asian-racism-and-covid-19

Hupka, S. (2020) As COVID-19 spreads, Asian students at BU see racism. Pipe Dream. https://www. bupipedream.com/news/115467/as-covid-19-spreads-asian-students-at-bu-see-racism/

Iftikar, J. S., \& Museus, S. D. (2018). On the utility of Asian critical (AsianCrit) theory in the field of education. International Journal of Qualitative Studies in Education, 31(10), 935-949.

Institute of International Education. (2019). Open Doors 2019 Fast Facts. https://www.iie.org/en/Resea rch-and-Insights/Open-Doors/Fact-Sheets-and-Infographics/Fast-Facts

Institute of International Education. (2020, November 16). United States hosts over 1 million international students for the fifth consecutive year. https://opendoorsdata.org/wp-content/uploads/2020/ 11/Open-Doors-2020-Press-Release.pdf

Janks, H. (1997). Critical discourse analysis as a research tool. Discourse, 18, 329-342. https://doi.org/ $10.1080 / 0159630970180302$

Juan, W. (2020). Racism and COVID-19: A Chinese students' perspective. Castleton Spartan. http:// www.castletonspartan.com/2020/04/07/racism-and-covid-19-a-chinese-students-perspective/

Kim, G. S., \& Shah, T. N. (2020). When perceptions are fragile, but also enduring: An Asian American reflection on COVID-19. Journal of Humanistic Psychology, 60(5), 604-610. https://doi.org/10. $1177 / 0022167820937485$

Kuo, L. (2020). Trump sparks anger by calling coronavirus 'the Chinese Virus.' The Guardian. https:// www.theguardian.com/world/2020/mar/17/trump-calls-covid-19-the-chinese-virus-as-rift-withcoronavirus-beijing-escalates 
Le, T. K., Cha, L., Han, H., \& Tseng, W. (2020). Anti-Asian xenophobia and Asian American COVID19 disparities. American Journal of Public Health, 110(9), 1371-1373. https://doi.org/10.2105/ AJPH.2020.305846

Lee, E. (2004). American gatekeeping: Race and immigration law in the twentieth century. In N. Foner \& G. M. Fredrickson (Eds.), Not Just Black and White. Russell Sage Foundation.

Lee, E. (2007). The "Yellow Peril"" and Asian Exclusion in the Americas. Pacific Historical Review, 76(4), 537-562. https://doi.org/10.1525/phr.2007.76.4.537

Lee, J. (2010). International students' experiences and attitudes at a U S host institution: Self-reports and future recommendations. Journal of Research in International Education, 9(1), 66-84. https://doi. org/10.1177/1475240909356382

Lee, J. J. (2020). International students shouldn't be political pawns. Inside Higher Education. https:// www.insidehighered.com/views/2020/07/08/government-regulationabout-international-studentsstrong-arming-colleges-resume

Lee, J., \& Rice, C. (2007). Welcome to America? International student perceptions of discrimination. Higher Education, 53, 381-409. https://doi.org/10.1007/s10734-005-4508-3

Lee, M. (2020). Coronavirus fears show how 'model minority' Asian Americans become the 'Yellow Peril'. NBC News. https://www.nbcnews.com/think/opinion/coronavirus-fears-show-how-modelminority-asian-americans-become-yellow-ncna1151671

Lee, J., Bean, F. D., Batalova, J., \& Sandhu, S. (2004). Immigration and the Black-White color line in the United States. In S. Shulman (Ed.), The impact of immigration on African Americans (pp. 27-58). Transaction Publishers.

Li, R. Y., \& Kaye, M. (1998). Understanding overseas students' concerns and problems. Journal of Higher Education Policy and Management, 20(1), 41-50. https://doi.org/10.1080/1360080980 200105

Litam, S. D. A. (2020). "Take your kung-flu back to Wuhan": Counseling Asians, Asian Americans, and Pacific Islanders with race-based trauma related to COVID-19. The Professional Counselor, 10(2), 144-156 https://doi.org/10.15241/sdal.10.2.144

Maxwell, J. A. (2005). Qualitative research design: An interactive approach (2nd ed., Vol. 41). Sage.

Mishra Tarc, A. (2013). Race moves: Following global manifestations of new racisms in intimate space. Race Ethnicity and Education, 16(3), 365-385. https://doi.org/10.1080/13613324.2011.645564

Museus, S. D., \& Iftikar, J. (2013). An Asian critical theory (AsianCrit) framework. Asian American Students in Higher Education, 31(10), 18-29.

NAFSA. (2020a). ICE's guidance limits decision-making authority of higher education leaders. https:// www.nafsa.org/about/about-nafsa/ices-guidance-limits-decision-making-authority-higher-educa tion-leaders

NAFSA. (2020b). NAFSA financial impact survey. https://www.nafsa.org/sites/default/files/media/ document/2020-financial-impact-survey.pdf

Organisation for Economic Co-operation and Development. (2016). OECD science, technology and innovation outlook 2016. Author.

Organisation for Economic Co-operation and Development. (2020). What is the profile of internationally mobile students? Education at a glance 2020: OECD Indicators. Author.

Perez Huber, L. (2011). Discourses of racist nativism in California public education: English dominance as racist nativist microaggressions. Educational Studies, 47(4), 379-401. https://doi.org/10.1080/ 00131946.2011 .589301

Perez Huber, L., Lopez, C. B., Malagon, M. C., Velez, V., \& Solorzano, D. G. (2008). Getting beyond the 'symptom', acknowledging the 'disease': Theorizing racist nativism. Contemporary Justice Review, 11(1), 39-51. https://doi.org/10.1080/10282580701850397

Redden, E. (2020). A bleak picture for international enrollment. Inside Higher Ed. Retrieved from https://www.insidehighered.com/news/2020/05/26/colleges-expect-few-new-international-studentswill-make-it-their-campuses-fall

Roberto, K. J., Johnson, A. F., \& Rauhaus, B. M. (2020). Stigmatization and prejudice during the COVID-19 pandemic. Administrative Theory \& Praxis, 42(3), 364-378. https://doi.org/10.1080/ 10841806.2020.1782128

Rose-Redwood, C., \& Rose-Redwood, R. (2017). Rethinking the politics of the international student experience in the age of Trump. Journal of International Students, 7(3), I-IX. https://doi.org/10. 32674/jis.v7i3.201

Rushin, S., \& Edwards, G. S. (2018). The effect of President Trump's election on hate crimes. Available at SSRN: https://ssrn.com/abstract=3102652

Said, E. (1978). Orientalism. Vintage Books.

Saini, M., \& Shlonsky, A. (2012). Systematic synthesis of qualitative research. Oxford University Press. 
Shahjahan, R. A., \& Kezar, A. J. (2013). Beyond the "national container" addressing methodological nationalism in higher education research. Educational Researcher, 42(1), 20-29.

Sherry, M., Thomas, P., \& Chui, W. H. (2010). International students: A vulnerable population. Higher Education, 60, 33-46. https://doi.org/10.1007/s10734-009-9284-z

Slaughter, S., \& Rhoades, G. (2004). Academic capitalism and the new economy: Markets, state, and higher education. Johns Hopkins University Press.

Smith, R. A., \& Khawaja, N. G. (2011). A review of the acculturation experiences of international students. International Journal of Intercultural Relations, 35, 699-713. https://doi.org/10.1016/j.ijintrel.2011. 08.004

Superpowered Insults. (2020, May 9). Superpowered insults: There is less trust between Washington and Beijing than at any point since 1979. The Economist, https://www.economist.com/united-states/2020/ 05/09/there-is-less-trust-between-washington-and-beijing-than-at-any-point-since-1979

Specia, M. \& Abi-Habib., M. (2020). U.S. visa changes stoke outrage from students who are now in limbo. The New York Times. https://www.nytimes.com/2020/07/09/world/international-students-visa-reaction. html

Stein, S., \& de Andreotti, V. O. (2016). Cash, competition, or charity: International students and the global imaginary. Higher Education, 72(2), 225-239. https://doi.org/10.1007/s10734-015-9949-8

Trammell, M. (2020). Racist "coronavirus" posters plastered on dorm room door led to Angelo State brawl, some say. San Angelo LIVE!. https://sanangelolive.com/news/crime/2020-04-01/racist-coronavirusposters-plastered-dorm-room-door-led-angelo-state-brawl

U.S. Immigration and Customs Enforcement. (2020, July 6). SEVP modifies temporary exemptions for nonimmigrant students taking online courses during fall 2020 semester. https://www.ice.gov/news/relea ses/sevp-modifies-temporary-exemptions-nonimmigrant-students-taking-online-courses-during

van Dijk, T. A. (2008). Critical discourse analysis. In D. Schiffrin, D. Tannen, \& H. E. Hamilton (Eds.), The handbook of discourse analysis (pp. 352-371). Blackwell.

Wilton, L., \& Constantine, M. G. (2003). Length of residence, cultural adjustment difficulties, and psychological distress symptoms in Asian and Latin American international college students. Journal of College Counseling, 6, 177-186. https://doi.org/10.1002/j.2161-1882.2003.tb00238.x

Winant, H. (2004). The new politics of race: Globalism, difference, justice. The University of Minnesota Press.

Wodak, R. (1995). Critical linguistics and critical discourse analysis. In J. Verschuren, J. A. Ostman, \& J. Blommaert (Eds.), Handbook of pragmatics: Manual (pp. 204-210). John Benjamins Publishing Company. https://doi.org/10.1075/hop.10.cri1

Yan, H., Chen, N. \& Nuresh, D. (2020, February 20). CNN. https://www.cnn.com/2020/02/20/us/coronavirus-racist-attacks-against-asian-americans/index.html

Yao, C.W. (2018). “They don't care about you”: Chinese international students' experiences with neo-racism and othering on a U.S. campus. Journal of the First-Year Experience and Students in Transition, $30(1), 87-101$.

Yao, C.W. (2021). Global positional competition and interest convergence: Student mobility as a commodity for U.S. academic imperialism. In J.J. Lee's (Ed.), Critical International Higher Education and Power: How US Internationalization is Not Neutral. Rutgers University Press.

Yao, C. W., George Mwangi, C. A., \& Malaney Brown, V. K. (2019). Exploring the intersection of transnationalism and critical race theory: A critical race analysis of international student experiences in the United States. Race Ethnicity and Education, 22(1), 38-58.

Yao, C. W., \& Viggiano, T. (2019). Interest Convergence and the Commodification of International Students and Scholars in the United States. Journal Committed to Social Change on Race and Ethnicity, 5(1), 81-109.

Publisher's Note Springer Nature remains neutral with regard to jurisdictional claims in published maps and institutional affiliations. 